\title{
Globalisasi dan Rezim Demokrasi Poliarki: Kebijakan Integrasi Ekonomi Indonesia
}

\section{Budi Winarno}

Jurusan Hubungan Internasional, Fakultas IImu Sosial dan IImu Politik, Universitas Gadjah Mada Kampus Bulaksumur, Yogyakarta

Email:winarno@ugm.ac.id

\begin{abstract}
Globalization on the one hand has reduced significantly the traditional roles of the state in the international level, while on the other hand it strengthened the positions of new transnational actors such as international organization, MNC, and society. At the domestic level, in many democratic nations, it changed the quality of democracy in which policies are no longer based on the interests of the people but to protect the penetration of global corporations. This article tries to explain, particularly in the case of Indonesia, how those decisions do not accommodate people as majority but only serve the interests of both local ruling elite and the transnational bourgeois. Democracy which ideally should be able to ensure the participation of the people in the decision making process apparently has been manipulated by a group of minority elites.

Keywords: globalization, polyarchy democracy, economic integration
\end{abstract}

\begin{abstract}
Abstrak
Globalisasi di satu sisi telah mengurangi secara signifikan peran tradisional negara dalam tingkat internasional, sementara di sisi lain memperkuat posisi aktor transnasional baru seperti organisasi internasional, MNC, dan masyarakat. Pada level domestik di banyak negara demokratis, hal ini merubah kualitas demokrasi yang kebijakannya tidak lagi berdasarkan kepentingan rakyat, namun unruk menjaga penetrasi kerjasama global. Artikel ini mencoba menjelaskan bagaimana keputusan tersebut tidak mengakomodasi rakyat sebagai mayoritas namun hanya melayani kepentingan elit lokal yang berkuasa dan borjuasi transnasional. Demokrasi yang secara ideal harus mampu memastikan partisipasi rakyat dalam proses pengambilan kepurusan, tampaknya telah dimanipulasi oleh sekelompok elit minoritas.

Kata Kunci: globalisasi, demokrasi poliarki, integrasi ekonomi.
\end{abstract}

\section{PENDAHULUAN}

Politik luar negeri suatu bangsa dilakukan dalam rangka meraih tujuan nasionalnya (Morgenthou, 1993). Ini biasanya dicapai melalui berbagai instrumen kebijakan luar negeri, dan di era globalisasi seperti sekarang, efektivitas politik luar negeri suatu bangsa beserta instrumen kebijakan yang menopangnya tidak lagi ditentukan oleh kekuatan-kekuatan konvensional, tetapi juga aktor-aktor baru yang melampaui lintas batas global. Di sini, ada batas-batas dalam sistem politik yang berasal dari lingkungan internasional dan global (Winarno, 2008) yang pada akhirnya berpengaruh terhadap "kinerja" sistem politik.

Salah satu perubahan lingkungan yang cukup signifikan sekarang ini adalah menajamnya globalisasi ekonomi, yang bagi negara nasional implikasinya berada dalam tiga hipotesis (Winarno, 2007). Pertama, negara sebagai aktor ekonomi akan menjadi anakronistik. Ini karena lingkup dan arti penting aktoraktor transnasional swasta meningkat, kontrol aparatus negara dalam batas hukum jurisdiksinya akan terbatas, 
dan dengan demikian semakin lemah. Dalam dunia baru, yaitu "dunia tanpa batas-batas negara ("a world without borders")", negara-negara dan penguasa militer tidak lagi memainkan peran penting. Bahkan, peran mereka semakin memudar, dan secara meyakinkan akan segera digantikan oleh peran yang semakin meningkat aktor-aktor nonteritorial, seperti perusahaan-perusahaan multinasional, gerakan-gerakan transnasional, dan organisasi-organisasi internasional (Keohane dan Nye, 1977: 3-4). Kedua, peran suatu negara bangsa akan ditentukan oleh posisinya dalam sistem dunia. Kekuasaan aktor-aktor transnasional yang berbasis di negara-negara inti akan mendorong peningkatan kekuasaan negara tersebut. Di sisi lain, meningkatnya aliran transnasional akan melemahkan negara-negara periferal dan pada waktu bersamaan menguatkan kekuasaan negara-negara inti. Terakhir, semakin meningkatnya aliran transnasional bagaimanapun akan meningkatkan peran penting negara di pusat ataupun di periferi. Dalam kaitan ini, arti penting aliran ekonomi transnasional secara simultan juga diiringi oleh peran negara (Green dan Luehrmann, 2003: 218; dalam Winarno, 2005).

Globalisasi, dalam beberapa hal, tampaknya memang "melemahkan" peran negara. Setidaknya, globalisasi neoliberal telah berusaha keras dalam usahanya menempatkan pasar pada posisi hegemonik, sedangkan pada waktu bersamaan berusaha memarginalkan peran negara (Priyono, 2003; lihat juga Harvey, 2009). Dalam konteks ini, negara telah berusaha atau dipaksa sedikit demi sedikit untuk keluar dari wilayah bonum commune. Ini karena, dalam neoliberalisme, paham yang menjadi ideologi di balik globalisasi ekonomi, normatif etis yang biasa disebut "kebaikan bersama" (bonum commune) tidak lagi dianggap sebagai tujuan yang secara intensional dikejar oleh agenda ekonomi-politik (intended motive), tetapi hanya sebagai hasil sampingan (unintended consequences) kinerja ekonomi politik. Sebaliknya, yang dikejar oleh agenda ekonomi-politik neoliberal adalah "the aсcumulation of individual wealth" (Priyono, 2004: 18). Di sini, globalisasi, pada satu sisi, menguatkan peran negara karena keberlangsungan prosesnya sangat ditentukan oleh proses dan keputusan politik, sedangkan pada sisi lain peran yang semakin menguat tersebut justru melemah ketika dihadapkan pada kekuatan-kekuatan transnasional. Negara tidak mampu berbuat banyak ketika berhadapan, misalnya, dengan rejim perdagangan internasional seperti World Trade Center (WTO), Bank Dunia, juga International Monetary Fund (IMF), dan perusahaan-perusahaan transnasional. Dalam situasi ini, menjadi menarik untuk mengkaji bagaimana kebijakan-kebijakan publik suatu negara pada kenyataannya tidak diorientasikan untuk kepentingan-kepentingan warga negara, tetapi lebih untuk melindungi kepentingan dan tujuan korporasikorporasi global (Hertz, 2005; Korten, 1997).

Kemudian, dalam kaitannya dengan sistem demokrasi, penting untuk dikaji bagaimana keputusan-keputusan politik dan kebijakan publik tidak melibatkan rakyat, tetapi hanya dirumuskan oleh segelintir elit berkuasa, baik elit politik dan borjuasi lokal maupun elit-elit transnasional? Demokrasi yang seharusnya mampu menjamin keterlibatan dan partisipasi rakyat dalam pengambilan kebijakan (Dahl, 1998) ternyata telah diselewengkan oleh sekelempok elit. Di sini, demokrasi telah menjadi bersifat poliarkis.

Tulisan ini dikembangkan berdasarkan hipotesis bahwa pengambilan kebijakan luar negeri (dalam hal ini perdagangan luar negeri) tidak didasarkan pada proses-proses demokratis, tetapi hanya sekelompok elit yang berkuasa. Globalisasi ekonomi yang melahirkan elit-elit transnasional telah mempertajam muatan demokrasi poliarkis dalam pengambilan kebijakan luar negeri. Padahal, kebijakan tersebut mempunyai imbas terhadap sebagian besar rakyat.

\section{PEMBAHASAN}

POLITIK GLOBALISASI DAN "KOOPTASI" POLITIK NASIONAL

Kaum hiperglobalis mengklaim bahwa globalisasi merupakan fenomena yang bersifat alamiah. Sayangnya, klaim ini tidak menemukan sandaran yang cukup meyakinkan. Klaim globalisasi alamiah menegasikan proses-proses politik yang mengiringinya. Padahal, jika kita merujuk konteks historis globalisasi, maka kita akan menemukan fakta bahwa menyebar dan 
meluasnya globalisasi ditopang oleh banyak keputusan politik. Oleh karena itu, globalisasi juga harus kita lihat sebagai proses politik sehingga globalisasi tidaklah bersifat sealamiah seperti yang disangkakan selama ini. Sebagaimana dikemukakan Prawiro (1998: 314-317), pergerakan globalisasi dipengaruhi oleh adanya dukungan tambahan yang sangat penting, yakni pemerintah dan perusahaan. Pertama, dalam globalisasi yang dipimpin oleh pemerintah (a goverment-led globalization), semua pemerintah, termasuk Indonesia cenderung memandang globalisasi secara ambivalensi. Tugas pemerintahan adalah kepada bangsa, dan melalui bangsa pemerintah mendapatkan kekuasaan dan legitimasi. Dalam kaitan ini, globalisasi membutuhkan negara bangsa untuk menyesuaikan diri dengan perjanjian-perjanjian global yang mungkin bertentangan dengan kepentingan-kepentingan dalam negeri. APEC merupakan contoh globalisasi yang diarahkan oleh pemerintah.

Di sisi lain, berbagai perundingan atau negosiasi di tingkat internasional dan gobal terus berlangsung diantara negara bangsa. Perundingan-perundingan tersebut diorientasikan untuk semakin membuka pasar-pasar dalam negeri. Ini merupakan proses politik sehingga, sebenarnya, tidak ada yang alamiah dalam proses globalisasi. Melalui berbagai perundingan ekonomi nasional semakin terintegrasi ke dalam perekonomian global, dan teknologi komunikasi bertindak sebagai katalis. Selebihnya, merupakan lobi dan keputusan politik pemerintahan nasional.

Dengan melihat globalisasi sebagai proses dan hasil keputusan-keputusan politik, maka bagaimana kebijakan-kebijakan perdagangan luar negeri dirumuskan akan lebih mudah diidentifikasi. Uraian berikut akan menjelaskan bagaimana implikasi globalisasi pada kekuasaan dan peran negara bangsa untuk selanjutnya dipaparkan bagaimana kekuatankekuatan global "mengkooptasi" proses pengambilan kebijakan suatu negara?

Globalisasi telah merongrong kekuasaan negara melalui integrasi pasar-pasar domestik sehingga negara tidak lagi mempunyai kemampuan yang cukup untuk mengontrol ekonomi nasional. Meskipun hal ini tidak berarti bahwa negara tidak sama sekali berperan. Kelompok skeptis telah mengingatkan mengenai peran negara ini dengan mengatakan bahwa kekuatankekuatan global itu sendiri sangat bergantung pada kekuatan mengatur pemerintahan nasional (Held, et.al., 1999). Dalam kasus Indonesia, kita akan melihat bagaimana pemerintahan yang lemah telah membuatnya mudah "dikendalikan" oleh kekuatankekuatan global. Meskipun demikian, globalisasi telah mentransformasi kekuasaan politik nasional, dalam pengertian memberikan batasan atas implementasi beberapa kekuasaan politik dan ekonomi yang dalam hubungan tradisional tidak tergoyahkan.

Salah satu yang dapat dilihat dari kecenderungan semacam ini adalah bagaimana integrasi perekonomian global telah menciptakan kesalingtergantungan dan kesalinghubungan ekonomi nasional sehingga tidak ada satu negara pun yang mampu membuat kebijakan ekonomi tanpa mempertimbangkan negara lain atau aktor-aktor lain dalam lingkungan internasional dan global. Dalam kaitan ini, David Held (1995) mengemukakan adanya lima keterputusan (disjuncture) pola-pola kekuasaan dan tekanan yang berubah yang sedang mendefinisikan kembali arsitektur kekuasaan politik di era globalisasi sekarang ini. Pertama, hukum internasional. Perkembangan hukum internasional telah menempatkan individu, pemerintahan, dan organisasi non-pemerintah di bawah sistem pengaturan resmi yang baru. Hukum internasional mengakui kekuasaan dan tekanan, hak dan kewajiban, yang mengatasi klaim-klaim negara bangsa dan yang, meskipun dalam pelaksanaannya, mereka tidak bisa didukung oleh institusi-institusi dengan keputusan memaksa. Kedua, internasionalisasi pembuatan keputusan politik. Menurut Held, wilayah utama keterputusan kedua antara teori negara berdaulat dan sistem global kontemporer terletak pada rejim-rejim dan organisasi-organisasi internasional yang sangat banyak yang dibentuk untuk, pada prinsipnya, mengatur keseluruhan bidang kegiatan transnasional (perdagangan, kelautan, ruang angkasa, dan sebagainya) dan masalah-masalah kebijakan kolektif. Perkembangan rejim-rejim dan organisasi-organisasi 
internasional telah membawa perubahan-perubahan penting dalam struktur pengambilan keputusan politik dunia. Bentuk-bentuk baru politik multilateral dan multinasional telah terbentuk dan bersamaan dengan itu terbentuk pula pola khusus pembuatan keputusan kolektif yang melibatkan pemerintahan nasional, IGO (International Government Organization), dan berbagai kelompok penekan transnasional serta INGO (International Non-Govermental Organization). Ketiga, kekuasaan hegemonik dan struktur keamanan internasional. Tumbuhnya kekuatan hegemonik dan dan munculnya aktor militer dan perkembangan negara-negara global, yang dicirikan oleh kekuasaan-kekuasaan yang besar dan blok-blok kekuasaan, kadang-kadang mengurangi otoritas dan integritas negara. Penempatan negara individu dalam hirarki kekuasaan global menentukan tekanan dan jenis-jenis pertahanan dan kebijakan luar negeri yang bisa dicari oleh pemerintah, khususnya pemerintah yang dipilih secara demokratis. Keempat, identitas nasional dan globalisasi budaya. Konsolidasi kedaulatan negara pada abad ke-18 dan ke-19 membantu perkembangan identitas rakyat sebagai subjek politik-sebagai warga negara. Ini berarti bahwa orang-orang yang tunduk kepada otoritas sebuah negara secara perlahan menjadi sadar akan hak keanggotaan mereka dalam suatu masyarakat dan sadar akan hak-hak dan kewajiban-kewajiban yang bisa diberikan keanggotaan semacam itu. Kelima, ekonomi dunia. Dalam konteks ini, terdapat keterputusan yang jelas antara otoritas formal negara dan jangkauan sistem produksi, distribusi, dan pertukaran kontemporer yang sering berfungsi membatasi wewenang dan keefektifan otoritas politik nasional. Kemajuan teknologi dalam teknologi informasi, komunikasi, dan transportasi tengah menghilangkan batas-batas diantara pasar yang terpisah-batas-batas yang merupakan prasyarat utama bagi kebijakan ekonomi nasional yang independen (Keohane dan Nye, 1991 seperti dikutip Held, 1995).

Pada kenyataannya, era globalisasi memunculkan aktor-aktor transnasional yang sangat berpengaruh, yang pengaruhnya, dalam tataran tertentu, mendeterminasi keputusan-keputusan politik dan kebijakan-kebijakan suatu negara, yakni perusahaanperusahaan transnasional dan lembaga-lembaga governance global.

Perusahaan-perusahaan transnasional merupakan aktor kunci di balik globalisasi ekonomi. Bahkan, dalam banyak hal, korporasi-korporasi global ini tidak dapat dikontrol (Yeates, 2002: 70; Sklair, 2001) oleh kekuasaaan politik negara. Perusahaan-perusahaan transnasional dan sekutu mereka merupakan aktoraktor politik, dan mereka menuai kesuksesan besar dalam menyampaikan pesan ke seluruh dunia bahwa tidak ada alternatif lain kecuali melalui jalan kapitalisme global. Jalan ke arah kemakmuran bersama ini, sebagaimana sering diargumentasikan oleh para korporat, adalah melalui kompetisi internasional yang diputuskan melalui 'free' market dan 'free' trade, (Yeates, 2002: 155) lembaga dan proses melalui mana mereka mengontrol baik melalui diri mereka sendiri maupun melalui sekutu mereka di tingkat lokal, nasional, regional, dan global.

Ada beberapa faktor pendukung semakin bagi semakin menguatnya pengaruh perusahaan-perusahaan transnasional dalam perekonomian global. Pertama, peran perusahaan-perusahaan transnasional semakin diperkuat oleh proses integrasi pasar keuangan global. Menguatnya integrasi pasar keuangan dunia ini telah membuat kontrol ekonomi korporasi menjadi sedemikian besar karena tidak ada satupun negara di dunia yang mampu mengontrol aliran modal global ini karena kurangnya kapasitas dan ketiadaan regulasi yang memadai. Kedua, merger dan akuisisi. Melalui proses ini, perusahaan-perusahaan transnasional mempunyai kemampuan ekonomi yang sangat besar. Bahkan, mengalahkan ekonomi beberapa negara. Desakan kompetisi dan keinginan untuk mendapatkan keuntungan sebesar-besarnya membuat beberapa korporasi melakukan merger dengan korporasi lain sebagai usaha untuk meningkatkan daya saing. Di Amerika Serikat, konsolidasi industri paling cepat terjadi pada kurun waktu 1897 sampai dengan 1904pada tahun-tahun itu, 4277 perusahaan mengerut menjadi 257. Ratusan perusahaan terbesar tersebut meningkat empat kali lipat ukurannya dan menguasai 
40 persen kapasitas industri negara (Tabb, 2003: 52 53).

Konsolidasi dalam bentuk M \& A tidak hanya terjadi diantara perusahaan-perusahaan yang beroperasi dalam batas-batas teritorial negara, tetapi melibatkan perusahaan-perusahaan besar multinasional seperti Nestle, Philip Morris, RJR Nabisco, dan Unilever. Hal yang sama juga terjadi pada perusahaan-perusahaan farmasi. Pada pertengahan tahun 1990-an, misalnya, M \& A perusahaan di bidang ini mencapai $\$ 80$ juta, termasuk di dalamnya 16 transaksi senilai $\$ 1$ juta (Scholte, 2000: 128). M \& A ini dalam perkembangannya telah mentransformasi pasar menjadi dikuasai oleh segelintir pelaku ekonomi besar, perusahaan-perusahaan transnasional. McLarenn dan Willmore (2003) mencatat bahwa lima ratus perusahan multinasional kini mengontrol hampir dua pertiga perdagangan dunia, dan jika dibuat daftar dalam suatu tabel perkumpulan ekonomi berdampingan dengan negara-negara bangsa, maka lebih separuh dari 100 ekonomi dunia adalah perusahaan-perusahaan multinasional. Lima perusahaan terbesar dunia secara bersama-sama menghasilkan angka penjualan tahunan lebih besar dibandingkan dengan kombinasi pendapatan 46 negara termiskin di dunia. Lebih jauh, David Held et.al (1999: 237-238) mencatat bahwa selama tahun 1998 terdapat 53,000 MNCs dengan 450,000 cabangnya di luar negeri. Seratus MNCs terbesar mengontrol kira-kira 20\% dari aset luar negeri dan mempekerjakan 6 juta tenaga kerja. MNCs menguasai $2 / 3$ perdagangan dunia, dan $1 / 3$ perdagangan dunia tersebut berlangsung intra-perusahaan antarcabang dalam suatu organisasi perusahaan yang sama. Kira-kira $50 \%$ perdagangan antara Jepang dan AS secara aktual terjadi dalam perusahaan (intrafirm trade). Selain itu, MNCs juga memainkan peran kunci dalam mengembangkan dan menyebarkan teknologi, kurang lebih $80 \%$ dari perdagangan dunia adalah dalam teknologi dan sejumlah besar share of private $R \mathcal{E} D$.

Selain perusahaan-perusahaan transnasional, aktor berikutnya yang mempunyai pengaruh besar di era globalisasi ekonomi ini adalah lembaga governance global. Salah satunya yang mempunyai pengaruh penting adalah World Trade Organization (WTO). Para pengritiknya mengatakan bahwa WTO merupakan puncak impian kaum neoliberal un tuk mendapatkan organisasi yang akan mengatur arah globalisasi ekonomi di tingkatan dunia (Setiawan, 2000). Meskipun secara konseptual lembaga ini merepresentasikan suatu bentuk organisasi yang demokratis, tetapi pada kenyataannya merepresentasikan hipotesis hubungan sentral-periferi. Negara-negara maju mempunyai kekuasaan yang lebih besar dalam mempengaruhi keputusan-keputusan dan negosiasi di tingkatan global. Melalui berbagai perundingan, negara-negara maju terus-menerus mendesakkan berbagai perjanjian dan kesepakatan yang memaksa negara-negara Dunia Ketiga untuk membuka pasar-pasar domestiknya, sementara pada saat bersamaan mereka melancarkan berbagai kebijakan proteksionisme.

Aktor berikutnya adalah lembaga-lembaga keuangan global. IMF dan Bank Dunia menjadi lembaga keuangan yang berpengaruh saat ini dalam memaksakan banyak prasyarat bagi usaha mendesakkan agenda globalisasi neoliberal. Seperti dicatat Kevin Danaher (2005: xliii-xliv), dua institusi yang paling berkuasa yang telah berhasil menegakkan agenda "pasar bebas" dari korporasi-korporasi raksasa atau perusahaan-perusahaan transnasional adalah Bank Dunia dan IMF. Dengan memberikan pinjaman ratusan milyar dolar kepada elit negara Dunia Ketiga, lebih lanjut Danaher mengemukakan, Bank Dunia dan IMF telah melakukan pengendalian signifikan terhadap strategi ekonomi kebanyakan negara. Mereka pun telah memaksakan seperangkat kebijakan (structural adjustment programs) suatu model ekonomi yang menguntungkan kaum minoritas, tetapi sangat mencelakakan kaum mayoritas.

Kritik atas Bank Dunia dan IMF tidak hanya sebatas prasyarat-prasyarat memaksa yang berasal dari kemampuannya dalam memberikan utang, tetapi juga struktur lembaga tersebut yang sangat bersifat elitis dan anti demokrasi. Kevin Danaher (hal. 21) dengan tajam mengkritik lembaga ini sebagai bersifat otokrasi: 
mereka sangat hirarkis dan elitis. Para elit di kedua lembaga tersebut mempunyai kekuasaan yang sangat besar atas kehidupan para buruh, nasabah, sejumlah bisnis kecil, dan bahkan seluruh masyarakat.

Merujuk Robert Dahl, Devest Kapur (2004: 103) mengkritik IMF dan Bank Dunia dengan menyatakan bahwa suatu kenyataan yang tidak menggembirakan mengenai institusi internasional ini ialah apapun governance dan pengambilan keputusan yang ada, kedua-duanya tidak akan demokratis dalam pengertian demokrasi sebagai suatu pengawasan oleh publik terhadap pengambilan keputusan. Secara struktural, menurut Kapur, organisasi internasional akan selalu menghadapi "defisit demokrasi". Bahkan, di negaranegara yang sudah lama memiliki struktur demokrasi yang berurat berakar sangatlah sulit bagi warga negaranya untuk melakukan pengawasan secara efektif terhadap keputusan penting mengenai urusan luar negeri; pengaruh mereka terhadap institusi internasional jauh lebih kecil lagi. Satu negara satu suara (seperti pada PBB) mungkin tampak lebih demokratis daripada satu dolar satu suara (seperti pada intitusi Bretton Woods System, IMF dan Bank Dunia), tetapi kedua-duanya menyalahi konsep kesetaraan dalam paham demokrasi yang inheren dalam satu orang satu suara.

Akhirnya, Bank Dunia dan IMF dituduh sebagai biang munculnya kemiskinan, yang pada akhirnya berimbas pada ketidaksetaraan politik dalam kontestasi demokrasi. Danaher (2006: 42) mengemukakan kritik tersebut sebagai berikut ini.

Program Penyesuaian struktural (SAPs) yang disertakan dalam pinjaman IMF dan Bank Dunia boleh jadi membantu negara-negara dalam membayar utang mereka terdahulu, dan boleh jadi juga menciptakan sejumlah jutawan. Namun, mayoritas penduduklah yang menjadi tumbalnya: upah yang rendah, berkurangnya pelayanan sosial, dan minimnya akses demokratis pada proses pembuatan kebijakan.

Bagi negara yang pernah mengalami kebangkrutan ekonomi, kekuasaan IMF dan Bank Dunia ini pasti pernah mereka rasakan. Ekonomi yang bangkrut, defisit anggaran yang membengkak, membuat negaranegara yang berada dalam situasi krisis tidak mempunyai pilihan lain kecuali meminta belas kasihan dari IMF.

Keseluruhan paparan di atas memberikan pelajaran bahwa globalisasi telah memunculkan aktor-aktor baru transnasional. Elit-elit transnasional yang lahir dari perusahaan-perusahaan global, WTO, IMF maupun Bank Dunia kini mempunyai kemampuan yang sangat besar dalam mempengaruhi kebijakan-kebijakan suatu negara. Perusahaan-perusahaan transnasional mendesakkan hasrat investasi yang bisa mengancam sewaktu-waktu untuk keluar dari dalam negeri jika kebijakan ekonomi-politik domestik tidak sejalan dengan kepentingan mereka. Ini belum termasuk lobilobi di tingkat pemerintah guna mendesakkan kebijakan-kebijakan yang lebih favourable bagi investasi dan usaha meraih keuntungan mereka. Sementara pada waktu bersamaan, memotong kebijakan-kebijakan prokaum buruh yang dalam pemahaman mereka merugikan. Bagaimanapun perusahaan-perusahaan transnasional mempunyai sumber daya memadai untuk memanipulasi kebijakan-kebijakan publik dibandingkan dengan warga negara biasa. Mereka juga mempunyai akses informasi yang lebih baik sehingga bisa memberikan respon atas rencana kebijakan yang akan diambil oleh pemerintah dalam kerangka yang lebih menguntungkan untuk mereka. Kemampuan memanipulasi kebijakan perusahaan-perusahaan transnasional ini menjadi semakin besar jika kita lihat kenyataan semakin mahalnya demokrasi liberal. Telah menjadi rahasia umum, baik di Amerika Serikat, Uni Eropa, maupun Indonesia bahwa kampanye partai politik dan juga kandidat presiden dibiayai oleh perusahaan-perusahaan swasta, baik nasional maupun transnasional. Terdapat aturan yang membatasi jumlah sumbangan, tetapi hal tersebut tetap tidak menghilangkan kekuatiran bahwa kebijakan-kebijakan pemerintahan yang berkuasa akan lebih ramah kepada perusahaan-perusahaan dibandingkan dengan masyarakat pemilih.

Sementara itu, melalui WTO, elit-elit negara maju terus-menerus mengenduskan globalisasi ekonomi 
neoliberal untuk kepentingan-kepentingan kolonialis mereka lepas dari aspirasi negara Dunia Ketiga. Sebaliknya, elit-elit nasional di negara-negara Dunia Ketiga secara membabi buta "membebek" pada keputusan-keputusan dalam tubuh WTO tanpa memperhatikan aspirasi rakyat di negaranya meskipun beberapa diantaranya melakukan perlawanan. Namun, pada akhirnya, mereka harus melaksanakan hasil-hasil perundingan yang merugikan kepentingan rakyatnya. Demikian pula, para penguasa di IMF dan Bank Dunia yang sebenarnya juga merepresentasikan kepentingan negara industri maju, tidak lupa memaksakan berbagai prasyarat dalam bentuk SAPs guna menopang jalannya globalisasi noeoliberal yang merusak tersebut.

Keseluruhan ini, pada akhirnya, mengkooptasi politik dalam negeri dalam memperjuangkan kepentingankepentingan nasional dan warga negara. Sebaliknya, lembaga-lembaga keuangan global seperti IMF dan Bank Dunia jauh lebih peduli dengan proyek-proyek ataupun kebijakan-kebijakan yang compatible dan mendukung globalisasi ekonomi yang timpang. Lembaga-lembaga ini lebih peduli terhadap upayaupaya meliberalisasi ekonomi perdagangan dan juga privatisasi perusahaan-perusahaan publik yang dalam banyak hal bertentangan dengan kepentingan warga negara di negara Dunia Ketiga. Stiglitz (2002; 2006), saya kira, telah memberikan komentar-komentar kritisnya terhadap hal ini. Dalam hal privatisasi, Stiglitz mengemukakan bahwa kebijakan privatisasi di negara-negara Dunia Ketiga yang dilanda krisis acapkali merupakan kebijakan yang tidak perlu, dilakukan dengan serampangan di tengah kerangka institusional yang belum mapan. Sementara dalam hal liberalisasi perdagangan, Stiglitz mmberikan komentar bahwa liberalisasi perdagangan menimbulkan efek-efek yang tidak terduga di negara Dunia Ketiga yang mengancam industri bayi (infant industry). Dalam kaitan ini, pembelaan Stiglitz adalah bahwa industri negara Dunia Ketiga memerlukan persiapan untuk mampu bersaing dengan negara-negara industri maju sehingga proteksi diperlukan terhadap industri mereka agar kuat.

Lebih lanjut, Stiglitz mengemukakan bahwa perdagangan bebas didasarkan pada efisiensi, dan ini akan sangat tergantung pada satu diantaranya sumber daya manusia dan kemampuan teknologi. Padahal, negara Dunia Ketiga tidak cukup memiliki sumber daya dan teknologi yang cukup. Akibatnya, perdagangan bebas tidak hanya menurunkan pendapatan karena penurunan tarif sebagai sumber penerimaan pemerintah di negara Dunia Ketiga, tetapi juga pada penurunan pajak. Ini pada akhirnya akan mendorong penurunan belanja publik. Di sisi lain, negara-negara Dunia Ketiga juga menderita karena tidak selalu menjadi pihak yang mendapatkan manfaat dengan adanya peningkatan ekspor karena minimnya infrastruktur untuk memindahkan barang-barang produksi mereka, dan yang kedua mereka memang tidak mempunyai barang yang dapat diekspor ke luar negeri.

Apa yang dikemukakan Stiglitz di atas merupakan suatu contoh dimana kebijakan yang diprakarsai IMF dan Bank Dunia tidak dirumuskan demi mengejar kemakmuran ekonomi warga negara, tetapi lebih untuk memenuhi hasrat korporasi untuk mengeruk keuntungan. Ini sejalan dengan prinsip yang mendasari keseluruhan kerja IMF dan Bank Dunia (Danaher, 2006: 53), yakni merangkul korporasi-korporasi besar agar berinvestasi di negara Dunia Ketiga. Jika investasi masuk, maka, asumsinya, akan menciptakan lapangan kerja dan kemudian meningkatkan pendapatan masyarakat di negara Dunia Ketiga. Namun, asumsi semacam ini seringkali luput karena adanya pertentangan antara kepentingan-kepentingan korporasi dan buruh. Dalam banyak kasus, buruh seringkali tidak mendapatkan hasil yang cukup untuk membiayai hidupnya karena minimnya upah, sedangkan di sisi lain negara tidak mampu berbuat banyak dalam menghadapi situasi semacam itu karena ancaman penarikan investasi.

Pemerintahan nasional terus-menerus mendapatkan tekanan dari semakin membengkaknya jumlah pengangguran. Padahal, pembangunan ekonomi yang mendorong penciptaan lapangan kerja menjadi salah satu sumber penilaian keberhasilan pemerintah. Jika pemerintah berhasil menurunkan angka pengangguran, maka meningkatkan legitimasinya dan membuka 
peluang bagi kembali terpilihnya rejim tersebut pada pemilu berikutnya. Sebaliknya, rejim pemerintahan yang gagal dalam menciptakan lapangan kerja bukan hanya akan menutup peluang untuk dipilih kembali dalam pemilihan umum berikutnya, tetapi juga akan membuka peluang bagi terjadinya instabilitas politik akibat gejolak di masyarakat. Oleh karena itulah, pemerintah sangat berhati-hati dalam menyikapi konflik buruh dengan perusahaan. Bahkan, sebagaimana disinyalir oleh Pierre Bourdieu (2003), pemimpin nasional seringkali merendahkan martabat status mereka dengan selalu menunduk di depan CEO perusahaan-perusahaan multinasional seperti Toyota, Daewoo, dan lain sebagainya, yang menurut Robinson disebut sebagai elit transnasional baru. Sebagaimana dikemukakan oleh Robinson (2003: 6-7), agen-agen ekonomi global ini adalah elit transnasional baru. Elitelit ini mengendalikan sistem keputusan dan secara cepat memonopoli kekuasaan masyarakat global melalui dominasi politik. Akibatnya, demokrasi yang dipromosikan oleh kelompok-kelompok ini lebih merupakan demokrasi poliarkis. Suatu sistem yang merujuk pada adanya sekelompok kecil yang benarbenar memiliki kekuasaan dan terikat langsung dalam pembuatan kebijakan, sembari hanya memberi kesempatan kelompok mayoritas pemilih mereka bersaing dalam pemilihan umum yang diawasi secara ketat. Robinson menyebutnya sebagai tipe "demokrasi pura-pura" yang sama sekali tidak melibatkan kekuasaan (cratos) dari massa rakyat (demos).

Kekuasaannya berakhir setelah kelompok elite kecil berkuasa dan menyebabkan semakin menganganya kesenjangan akibat ekonomi global.

\section{DEMOKRASI POLIARKI}

Ungkapan demokrasi poliarki diperkenalkan oleh Robert Dahl (1998: 90) untuk membedakannya dengan suatu bentuk pemerintahan yang diatur oleh monarki atau oligarki. Konsep yang dikemukakan oleh Robert Dahl ini menarik karena setidaknya dua alasan. Pertama, demokrasi memang mempunyai sifat-sifat ideal setidaknya dalam konsepsi teoritiknya. Sebagaimana dikemukakan oleh Robert Dahl (1998:
38), demokrasi akan menjamin hak-hak politik warga negara, pembangunan manusia, kemakmuran, menghindarkan tirani, jaminan akan hak-hak dasar, dan lain sebagainya. Dalam prosesnya, suatu sistem dikatakan demokratis jika setidaknya mengandung lima kriteria, yakni partisipasi yang efektif, persamaan dalam memberikan suara, pemahaman yang jernih dari warga negara atau anggota suatu kelompok asosiasi, pengawasan agenda, dan pencakupan orang dewasa. Namun, acapkali terjadi, demokrasi tidak memberikan kesempatan semacam itu. Sebaliknya, proses pemilu yang mahal telah membuatnya terjebak ke dalam demokrasi prosedural yang lebih menjamin kelompok kaya untuk memegang tampuk pemerintahan karena kemampuan manipulasi melalui berbagai proyek pencitraan. Demokrasi, dengan demikian, mengalami proses penyerobotan oleh elit-elit politik lokal dan nasional yang tujuan dasarnya sebatas meraih kekuasaan. Dengan kata lain, demokrasi prosedural yang mengandalkan suara terbanyak berdasarkan prinsip one man one vote juga acapkali mudah diselewengkan untuk kepentingan pragmatis elit, baik ekonomi maupun politik. Kedua, demokrasi partisipatif yang setara memerlukan akses dan informasi yang tersedia untuk seluruh warga negara. Sayangnya, prasyarat ini hampir tidak pernah bisa dipenuhi. Informasi selalu timpang. Kelompok kaya selalu mendapatkan lebih banyak informasi, sedangkan masyarakat miskin tidak demikian. Akibatnya, kualitas partisipasi masing-masing warga negara mempunyai derajat yang sangat berbeda. Ini pada akhirnya berimplikasi pada kemampuan masing-masing kelompok dalam memanipulasi kebijakan. Perusahaanperusahaan transnasional karena sumber daya yang dimiliki mempunyai kemampuan memanipulasi kebijakan publik yang lebih besar dibandingkan dengan warga negara kebanyakan sebagaimana telah dibahas sebelumnya.

Di era globalisasi sekarang ini, muatan demokrasi poliarkis menjadi semakin kuat. Keberadaan elit-elit transnasional seperti WTO, IMF, dan Bank Dunia, dan perusahaan-perusahaan transnasional, misalnya, membuat pemerintahan nasional yang berdaulat 
semakin tidak mempunyai kesempatan untuk mengkonsultasikan kebijakan-kebijakan publik melalui debat publik yang panjang. Dalam situasi ekonomi bangkrut seperti krisis ekonomi 1998, bangsa Indonesia sepertinya tidak mempunyai banyak pilihan kecuali utang kepada IMF. Tentu saja, utang diberikan dengan syarat Indonesia melakukan kebijakan yang bersandar pada tiga hal pokok, yakni liberalisasi, deregulasi, dan privatisasi. Suatu kebijakan ekonomi khas neoliberal. Pilihan kebijakan semacam ini tidak saja tanpa melalui "konsultasi publik" layaknya yang berlaku dalam sistem demokrasi, tetapi dirumuskan oleh segelintir elit politik di Jakarta. Padahal, akibat-akibat kebijakan tersebut mempunyai dampak luas bagi hampir seluruh rakyat Indonesia. Utang yang besar jelas membebani APBN yang membuat anggaran pendidikan dan kesejahteraan sosial jauh berkurang. Sementara pada waktu bersamaan, liberalisasi tanpa kendali di sektor pertanian dan perkebunan justru menghancurkan produktivitas sektor tersebut (Primahendra, 2006), sekaligus menciptakan ketergantungan (Khudori, 2008). Keseluruhan proses tersebut pada akhirnya membuat petani semakin termarginalkan.

Secara tradisional, sebenarnya, tujuan penyelenggaraan pemerintahan demokrasi adalah untuk mencegah akumulasi kekuasaan ke dalam satu atau beberapa orang. Demokrasi sebagaimana dikemukakan Winston Churchil sebagai 'least bad' form of government. Dengan menciptakan sistem dimana publik dapat mengganti pemerintahan dengan tanpa mengubah aturan dasarnya dalam penyelenggaraan pemerintahan tersebut, penyelenggaraan sistem pemerintahan demokrasi bertujuan untuk mengurangi ketidakpastian dan instabilitas, dan menjamin warga negara yang tidak sepakat dengan kebijakan saat ini dengan memberikan kesempatan berkala untuk mengganti siapa saja yang memegang kekuasaan, dan dengan demikian mempunyai otoritas membuat kebijakan. Mereka dapat mengubah kebijakan yang tidak mereka setujui dengan melakukan tekanantekanan politik kepada rejim yang sedang berkuasa.

Dalam kaitannya dengan kebebasan individu, Robert Dahl (1998: 2) menegaskan bahwa demokrasi memberikan jaminan kebebasan yang tidak tertandingi oleh sistem politik manapun. Secara instrumental, demokrasi mendorong kebebasan melalui tiga cara (Diamond, 2003: 3-4), yakni: pertama, pemilu yang bebas dan adil yang secara inheren mensyaratkan hakhak politik tertentu untuk mengekspresikan pendapat, berorganisasi, oposisi, serta "hak-hak politik mendasar semacam ini tidak mungkin hadir" tanpa pengakuan kebebasan sipil yang lebih luas. Kedua, demokrasi memaksimalkan peluang bagi penentuan nasib sendiri (self determination), "setiap individu hidup di bawah aturan hukum yang dibuat oleh dirinya sendiri”. Ketiga, demokrasi mendorong otonomi moral, yakni kemampuan setiap negara untuk melakukan pilihanpilihan normatif, dan karenanya pada tingkat yang paling mendalam, demokrasi mendorong kemampuan untuk memerintah sendiri (self governing).

Namun, bagaimanapun idealnya, prasyarat demokrasi sebagaimana dikemukakan di awal, seringkali tidak dipenuhi. Di sisi lain, kecenderungan demokrasi ternyata justru melawan pandangan umum yang diyakini banyak orang dimana demokrasi akan terjebak ke dalam tirani mayoritas. Seperti dikemukakan oleh Tocqueville, prinsip mayoritas yang merupakan substansi dalam sistem pemerintahan demokratis dianggap akan memunculkan suatu produk hukum yang hanya akan melayani kehendak dan kepentingan mayoritas. Mayoritas sebagaimana dipahami oleh Tocqueville (1966) adalah kemampuan kolektif dengan pendapat dan biasanya dengan kepentingan yang bertentangan dengan kehendak dan kepentingan individu-individu yang lain, yang disebut sebagai minoritas. Demokrasi, sebaliknya, terjebak ke dalam sifat poliarkis dimana kebijakan dirumuskan oleh segelintir orang yang, dalam banyak hal, tidak bertanggung jawab terhadap kedaulatan rakyat. Padahal, legitimasi pemilihan umum dalam sistem demokrasi diselenggarakan sebagai usaha mewujudkan kedaulatan tersebut. Namun, dalam praktiknya, jauh dari kenyataan demikian. Oleh karena itu, penulis seperti Giddens (1994) menerima konsep demokrasi liberal sebagai demokrasi perwakilan dan tidak mengakui bentuk partisipasi langsung oleh mereka 
yang diperintah dalam proses pemilihan pemerintahan. Menurut Giddens, demokrasi ini hanya dibatasi pada wilayah politik; dalam wilayah produksi, pekerja tidak memiliki hak atas nasibnya sendiri segera setelah mereka memasuki ruang kerja setiap hari. Seperti dikemukakan Giddens, "demokrasi liberal, yang akan saya terima, pada dasarnya adalah demokrasi sebagai suatu sistem representasi”.

\section{INTEGRASI EKONOMI INDONESIA: DARI ELIT UNTUK ELIT?}

Kebijakan ekonomi Indonesia dalam usahanya untuk terus-menerus terlibat dalam integrasi ekonomi dunia mencerminkan suatu tipe pengambilan kebijakan yang bersifat poliarkis. Akhir tahun 1980an, Indonesia telah melancarkan serangkaian kebijakan yang ditujukan untuk semakin memperluas basis ekonomi swasta, baik nasional maupun internasional. Kebijakan ini terus berlanjut pada era tahun 1990-an saat Indonesia masuk ke dalam organisasi perdagangan dunia, WTO. Konsekuensi atas masuknya Indonesia ke dalam WTO ini amatlah jelas, yakni secara konsisten harus meliberalisasi perekonomian dalam negeri sesuai dengan mandat yang diberikan oleh WTO.

Pada penghujung tahun 1990-an ketika Indonesia mengalami serangkaian krisis moneter, usaha untuk mengintegrasikan diri ke dalam perekonomian global semakin gencar dilakukan. Ini dilakukan sebagai konsekuensi logis utang Indonesia kepada IMF untuk mengatasi krisis moneter waktu itu. Prasyarat mencarikan utang maka Indonesia harus melakukan serangkaian kebijakan yang termaktub dalam LoI. Isinya, tidak lain merupakan serangkaian kebijakan yang berbasis pada Konsensus Washington. Beberapa kebijakan pokok berdasarkan LoI ini diantaranya adalah liberalisasi di sektor pertanian.

Beberapa kebijakan hasil dari kesepakatan dengan IMF di sektor ini adalah penurunan tarif impor dan ekspor hingga 0 persen. BULOG juga direformasi sehingga tidak lagi diijinkan melakukan monopoli kecuali untuk komoditas beras. Sistem tanam yang diwajibkan kepada petani dihapuskan, dan berbagai fasilitas yang banyak dinikmati petani mulai dihilangkan satu per satu. Pertanyaannya kemudian adalah bagaimana implikasi kebijakan ini bagi nasib petani?

Kebijakan neoliberal di sektor ini ternyata tidak hanya membuat petani semakin kesulitan, tetapi juga menciptakan bentuk baru ketergantungan sektor pertanian. Periode 1989-1991, Indonesia merupakan negara pengeskpor pangan (net exporter) dengan nilai sekitar US\$ 418 juta/per tahun. Namun, sejak tahun 1994, Indonesia beralih menjadi pengimpor pangan. Pada tahun 2003, sebagai akibat liberalisasi yang makin intensif, Indonesia mengalami defisit perdagangan sebesar US $\$ 1,4$ miliar untuk tanaman pangan dan US\$134,4 juta untuk peternakan (Primahendra, 2006: 229). Dalam hal impor, pada periode 1998-2000, Indonesia mengimpor pangan rata-rata US $\$ 863$ juta per tahun. Selama periode 1996-2003, Indonesia mengimpor beras 2,83 juta ton, gula 1,6 juta ton, jagung 1,2 juta ton, kedelai 0,8 juta ton serta beberapa bahan pangan lainnya (Witoro, 2006: 136).

Ditinjau dari dampak-dampak kebijakan publik liberalisasi, dan dengan demikian merupakan rangkaian kebijakan Indonesia untuk mengintegrasikan pasar domestiknya ke dalam perekonomian global, liberalisasi sektor pertanian mempunyai dampak buruk. Namun, kebijakan tersebut tetap dilaksanakan. Ironisnya, petani yang menjadi kelompok terbesar dalam pemilu tidak pernah dilibatkan dalam proses pengambilan kebijakan, yang nota bene mempunyai pengaruh besar dalam kehidupan mereka. Sebaliknya, melalui perundingan dengan IMF liberalisasi sektor pertanian diputuskan dengan tanpa mempertimbangkan suara dan nasib petani.

Di luar WTO dan desakan IMF, Indonesia juga terlibat secara aktif dalam membangun aliansi-aliansi ekonomi strategis yang bermuara pada integrasi perekonomian Indonesia dalam lingkup global. Dalam hal integrasi pasar ASEAN, Indonesia menjadi salah satu penggerak yang terus-menerus mempromosikan pentingnya pasar bebas ASEAN. Para pengambil kebijakan di tingkat pusat mempunyai keyakinan ideologis bahwa hanya melalui perdagangan bebaslah 
ekonomi Indonesia akan menjadi lebih baik, dan dengan demikian kemakmuran dan kesejahteraan akan lebih mudah dicapai.

Sayangnya, keyakinan-keyakinan para pengambil kebijakan ini bertentangan, dalam banyak kasus, dengan keluhan-keluhan masyarakat di tingkat bawah. Pembukaan pasar-pasar dalam negeri telah menggerus kemampuan industri dalam negeri yang tidak kompetitif. Sektor pertanian menjadi contoh dalam hal ini. Industri tektil menjadi contoh lainnya.

Suatu pertanyaan pokoknya adalah jika kebijakankebijakan yang diorientasikan untuk mengintegrasikan diri ke dalam perekonomian global merugikan pengusaha-pengusaha kecil dalam negeri dan petani, maka bagaimana mungkin kebijakan tersebut tetap dipertahankan? Jawaban atas hal ini terletak pada perubahan struktur kekuasaan dalam lingkungan global yang telah berubah sebagaimana telah dipaparkan sebelumnya. Bagaimanapun negara-negara akan mempunyai keterbatasan dalam mendesakkan agenda nasional lepas dari pertimbangan kekuatankekuatan global yang juga bersifat poliarkis. Situasi ini akan menjadi semakin buruk jika dilihat kenyataan karakteristik kekuasaan dan kelembagaan Indonesia baik sebelum maupun sesudah reformasi. Dalam kaitan ini, Vedy R. Hadiz (2005: 263) mengemukakan adanya delapan karakterisk kelembagaan baru Indonesia pasca-reformasi. Pertama, deseNtralisasi kekuasaan kepresidenan kepada lembaga-lembaga seperti partaipartai politik dan parlemen. Kedua, kebangkitan partaipartai politik, yang tidak disatukan oleh agenda-agenda sosial, ekonomi dan politik yang bersifat spesifik dan konkret, melainkan sekadar merupakan ekspresi dari pergeseran koalisi-koalisi kekuasaan. Kepentingankepentingan predatoris lama umumnya masih bercokol di dalam partai-partai ini, ditambah dengan segelintir unsur-unsur reformis yang biasanya termarjinalisasi. Ketiga, desentralisasi kekuasaan dari Jakarta ke daerah-daerah. Oleh karena itu, pejabatpejabat lokal seperti bupati dan walikota, cabangcabang partai dan parlemen di tingkat lokal memperoleh arti penting baru. Keempat, munculnya jaringan-jaringan patronase yang desentralistik, tumpang-tindih, dan tersebar yang didasarkan atas persaingan memperebutkan akses dan kontrol terhadap lembaga-lembaga dan sumber-sumber daya negara di tingkat nasional maupun lokal. Kelima, munculnya bandar-bandar, pialang dan kriminal politik yang sebelumnya berada pada lapisan-lapisan terbawah dalam sistem patronase Orde Baru. Keenam, terkait dengan itu, kebangkitan para hooligan dan kriminal yang terorganisasi dalam milisi partai, kekuatan-kekuatan paramiliter, serta berbagai laskar Islam, dimana banyak dari mereka yang mengambil alih fungsi-fungsi tertentu militer (misalnya, dalam mengintimidasi buruh dan para aktivis). Ketujuh, kontrol-kontrol yang terlalu otoritan digantikan oleh penggunaan politik uang dan politik kekerasan serta intimidasi, baik di tingkat nasional maupun lokal. Kedelapan, kedudukan penting pemilihan umum, termasuk ditingkat lokal, terutama karena kecenderungan-kecenderungan yang mengarah pada otonomi daerah (yang hingga sekarang masih belum terdefinisikan secara memadai). Kesembilan, peran militer senagai sebuah lembaga. Setelah militer diturunkan dari polisi 'bodyguard' rezim pada tahuntahun akhir Soeharto, partai-partai dan para politisi di era pasca-Soeharto belum mampu untuk mengabaikan kepentingan-kepentingan mereka. Isu yang ramai diperdebatkan adalah sistem teritorial yang telah menjadi dasar bagi komandan-komandan lokaluntuk masuk ke dalam alinasi-alinasi bisnis maupun politik dan menanamkan pengaruhnya di setiap tingkat, serta keterlibatan militer dalam berbagai aktivitas bisnis (misalnya di bidang kehutanan).

Keseluruhan karakteristik kelembagaan ini pada akhirnya membuat "sabotase" demokrasi jauh lebih berjalan mulus. Demokrasi poliarkis semakin kuat dengan keuntungan berada di lingkaran elit melalui patronase dan perburuan rente ekonomi dalam lingkaran kekuasaan (Hadiz, 2005). Kebijakan ekonomi luar negeri dengan demikian lebih berorientasi pada kemauan ideologis para pelaku pasar utama dibandingkan dengan memperjuangkan kepentingan rakyat dalam pengertian sesungguhnya. 


\section{KESIMPULAN}

Keseluruhan paparan di atas memberikan gambaran bagaimana demokrasi telah cenderung bersifat poliarkis. Globalisasi yang memunculkan elit-elit transnasional baru pada akhirnya mempertajam muatan demokrasi poliarkis dengan menyerobot proses-proses demokrasi.

Untuk mengatasi hal tersebut, barangkali, muatan demokrasi deliberatif ini dapat dipertimbangkan. Ini karena setidaknya tiga alasan, yang sekaligus menjadi ciri demokrasi model ini. Pertama, partisipan mendapatkan jaminan guna menawarkan argumentasi persuasif yang ditujukan untuk partisipan yang lain dalam suatu proses deliberatif. Standar yang diterima oleh para pendukung demokrasi deliberatif bahwa partisipan dalam proses-proses deliberatif tidak hanya dibutuhkan untuk menawarkan argumen, tetapi menawarkan argumen persuasif yang ditujukan untuk semua. Kedua, partisipan dalam demokrasi deliberatif mempunyai komitmen untuk merespon alasan dan argumentasi partisipan yang lain juga melalui alasan dan argumen. Apa yang dimaksud dengan deliberation bukanlah menyangkut tawar-menawar kekuasaan, tetapi hanya menguatkan argumentasi yang lebih baik: partisipan memberikan alasan-alasan mereka 'dengan harapan bahwa alasan-alasan itu akan meyakinkan usulan mereka'. Ketiga, partisipan dalam demokrasi deliberatif bersedia merevisi usulan yang mereka ajukan dalam rangka mendapatkan kesepakatan yang dapat diterima secara bersama-sama.

\section{BIBLIOGRAFI}

Bourdieu, Pierre. 2003. Kritik Terhadap Neoliberalisme: Utopia Eksploitasi Tanpa Batas Menjadi Kenyataan. Basis, Nomor 11-12, Tahun ke-52, November-Desember.

Dahl, Robert. 1998. On Democracy. Yale University Press

Danaher, Kevin. 2006. 10 Alasan Bubarkan IMF dan Bank Dunia. Yogyakarta: Cindelaras

Diamond, Larry. 2003. Developing Democracy: Toward Consolidation. Yogyakarta: IRE Press.

Festenstein, Matthe. 2004. Deliberative Democracy and Two Pragmatism. European Journal of Social Theory, 7(3): 291-306.

Giddens, Anthony. 1994. Beyond the Left and Right: The Future of Radical Politics. Cambridge: Polity Press

Hadiz, Vedy R. 2005. Dinamika Kekuasaan: Ekonomi Politik Indonesia Pasca-Soeharto. Jakarta: LP3ES
Held, David at.al. 1999. Global Transformations: Politics, Economic, and Culture. Stanford, California: Stanford University Press

Held, David. 1995. Democracy and the Global Order, Stanford: Stanford University Press.

Held, David. 2001. Globalization, Cosmopolitanism, and Democracy: an Interview. First published in the journal IDEES of the Centre d'Estudis de Temes Contemporanis, Generalitat de Catalunya. (Online), (http://www.polity.co.uk/global/held.htms)

Kapur, Devest. 2004. Anatomi Governance Bank Dunia. Dalam Jonathan R. Pincus dan Jeffery Winters. Membongkar Bank Dunia. Jakarta: Jambatan

Korten, David. 1997. When Corporations Rule The World, (Bila Korporasi Menguasai Dunia). Jakarta: Profesional Books

McLarenn, Duncan and lan Willmore. 2003. The Growing of Big Bussiness. Open Democracy, 20 February.

Primahendra, Riza. 2006. Tata Kelola Globalisasi dan Dampaknya: Pekerjaan Rumah untuk Indonesia. Dalam Sugeng Bahagijo (ed.). Globalisasi Menghempas Indonesia. Jakarta: LP3ES

Priyono, Herry B. 2003. Dalam Pusaran Neoliberalisme. Dalam I. Wibowo dan F. Wahono (ed.) Neoliberalisme. Yogyakarta: Cindelaras Pustaka Rakyat Cerdas.

Robinson, William I. 2003. Neoliberalisme, Elit Global, dan Transisi Guatemala: Sebuah Analisis Kritis Makrostruktural. Dalam William I. Robinson (ed.). Hantu Neoliberalisme. Jakarta: C-Books.

Scholte, Jan Art. 2000. Globalization: A Critical Introduction. New York: St. Martin Press

Sklair, Leslie. 2001. Globalization: Capitalism and It's Alternative. Oxford University Press.

Sklair, Leslie. 2002. Demokrasi and Transnational Capitalis Class. ANNAL, AAPSS, 581, Mei.

Stiglitz, Joseph. 2002. Globalization and Its Discontents. Allen Lane: Pinguin Books

Tocqueville, Alexis De. 1966. Democracy in America. Dalam Ricardo Blaug and John Schwarzmantel (ed.). Democracy: A Reader, Edinburg University Press.

Winarno, Budi. 2005. Globalisasi dan Krisis Pembangunan: Bagaimana dengan Indonesia?. Pidato Pengukuhan Guru Besar pada fakultas IImu Sosial dan IImu Politik Universitas Gadjah Mada.

Winarno, Budi. 2007. Globalisasi dan Krisis Demokrasi. Yogyakarta: Media Peressindo

Winarno, Budi. 2008. Sistem Politik Indonesia Era Reformasi. Yogyakarta: Media Pressindo.

Witoro. 2006. Memperdagangkan Kehidupan: Menelisik Nasib Beras di Bawah Pasal-pasal WTO. Dalam Sugeng Bahagijo (ed.). Globalisasi Menghempas Indonesia. Jakarta: LP3ES

Yeates, Nicola. 2002. Globalization and Social Policy: From Global Neoliberal Hegemony to Global Political Pluralism. Global Social Policy, Vol 2 (X), 69-91. 